\title{
The Role of Probiotics in Various Diseases
}

Sulthan Al Rashid

\begin{abstract}
:
We know that probiotics are found to be useful in various conditions like irritable bowel syndrome, opioid tolerance, indigestion, depression, anxiety, and ADHD. But still, we don't know the proper mechanism involved in the treatment of these conditions by probiotics supplementation. In this Letter to Editor, I have written one interesting hypothesis which connects probiotics' common mechanism of action to all these diseases.
\end{abstract}

Kevwords: Probiotics, Opioids, Diseases, CNS, GIT.

We know that probiotics are found to be useful in various conditions like irritable bowel syndrome, ${ }^{1}$ opioid tolerance, ${ }^{2}$ indigestion, ${ }^{3}$ depression, ${ }^{4}$ anxiety, ${ }^{5}$ and ADHD $^{6}$. But still, we don't know the proper mechanism involved in the treatment of these conditions by probiotics supplementation. In this article, I would like to write one interesting hypothesis which connects probiotics' common mechanism of action to all these diseases.

I will start with irritable bowel syndrome. It has been found that two bacterial floral species are deficient in irritable bowel syndrome i.e. Lactobacillus and Bifidobacterium. ${ }^{7}$ They produce lactic acid in the colon. ${ }^{8}$ Normally, gastric acid secretion (acidic $\mathrm{pH}$ ) releases endogenous opioids endorphin which increases bicarbonate secretion and thereby helping in digestion. ${ }^{9}$ Irritable bowel syndrome is a functional gastrointestinal disorder where the digestion mechanism is impaired. ${ }^{10}$ By replacing the probiotics Lactobacillus and Bifidobacterium, it will decrease intraluminal $\mathrm{pH}$ by producing lactic acid which may be the source of release of endogenous opioids which helps in digestion by increasing bicarbonate secretion ${ }^{9}$ and stops diarrhea by stimulating mu-opioid receptors in the intestine. ${ }^{11}$ So, this hypothesis covers the treatment of two important conditions indigestion and diarrhea dominant irritable bowel syndrome by replacing with probiotics.
Now I will talk about the probiotic's role in treating opioid tolerance. In patients with opioid tolerance, it has been found that their gut microflora is altered deficient in the same Lactobactillus and Bifidobacterium. $^{2}$ So, when they tried giving opioids with probiotics, they found improvement in opioid actions by relieving the tolerance. ${ }^{2}$ So, the possible mechanism of treating this opioid tolerance is also the same i.e. probiotics, by producing lactic acid (creating acidic $\mathrm{pH}$ ) induces the release of endogenous opioids which stimulates mu-opioid receptors in the intestine which further activates mu receptor in the CNS probably through gut-brain axis mechanism. ${ }^{12}$ Since mu receptors in the CNS get stimulated, tolerance finally gets relieved.

Lastly, I will talk about the probiotic's role in treating anxiety, depression, and ADHD. For that, I have to explain the gut-brain axis mechanism first. ${ }^{12}$ The gut-brain axis mechanism comprises two-way communication between ENS and CNS which connects the function of the intestine with behavioural centres of the brain. ${ }^{12}$ Recent research is saying that bacterial flora in the gut is responsible for these connections. ${ }^{12}$ This connection is two-sided from bacterial microflora in the intestine to CNS and from CNS to bacterial microflora in the intestine through the various process like signalling by neural, hormonal, immune-mediated, etc. ${ }^{12}$ In this article, I have

Correspondence to: Department of Pharmacology, Jawaharlal Nehru Medical College, Aligarh Muslim University, Aligarh, Uttar Pradesh. E-mail: sulthanalrashid@gmail.com 
hypothesised the gut-brain mechanism by neural signalling pathway i.e. mu-opioid receptors from ENS to mu-opioid receptors in CNS and the same from CNS to ENS. And this neural mechanism is initiated by probiotics in this case, by producing lactic acid (creating acidic $\mathrm{pH}$ ) induces the release of endogenous opioids which stimulates muopioid receptors in the intestine which further activates mu receptor in the CNS probably through this neural gut-brain axis mechanism. Since mu receptors in the CNS get stimulated the patients of anxiety, depression, and ADHD will find relief because of the central actions of opioids like sedation, ${ }^{13}$ mood stabilisation, ${ }^{14}$ etc. All this happens because of this important hypothesis i.e. Probiotics release endogenous opioids by creating an acidic environment in the intestine due to lactic acid production.

\section{References:}

1. Aragon G, Graham DB, Borum M, Doman DB. Probiotic therapy for irritable bowel syndrome. Gastroenterol Hepatol (N Y). 2010;6(1):39-44.

2. Zhang L, Meng J, Ban Y, Jalodia R, Chupikova I, Fernandez I, Brito N, Sharma U, Abreu MT, Ramakrishnan S, Roy S. Morphine tolerance is attenuated in germfree mice and reversed by probiotics, implicating the role of gut microbiome. Proc Natl Acad Sci U S A. 2019;116(27):13523-32.

3. Igarashi M, Nakae H, Matsuoka T, Takahashi S, Hisada T, Tomita J, Koga Y. Alteration in the gastric microbiota and its restoration by probiotics in patients with functional dyspepsia. BMJ Open Gastroenterol. 2017;4(1).

4. Wallace CJ, Milev R. The effects of probiotics on depressive symptoms in humans: a systematic review. Ann Gen Psychiatry. 2017;16(1):14.

5. Huang R, Ning H, Yang L, Jia C, Yang F, Xu G, Tan H. Efficacy of probiotics on anxiety: a meta-analysis of randomized controlled trials. Neuropsychiatry. 2017;7(6):862-71.

6. Kumperscak HG, Gricar A, Ülen I, Micetic-Turk D. A Pilot Randomized Control Trial With the Probiotic Strain Lactobacillus rhamnosus GG (LGG) in ADHD: Children and Adolescents Report Better HealthRelated Quality of Life. Front Psychiatry. 2020;11.

7. Rodiño-Janeiro BK, Vicario M, Alonso-Cotoner C,
Pascua-García R, Santos J. A review of microbiota and irritable bowel syndrome: future in therapies. Adv Ther. 2018;35(3):289-310.

8. Molska M, Reguła J. Potential mechanisms of probiotics action in the prevention and treatment of colorectal cancer. Nutrients. 2019;11(10):2453.

9. Flemström G, Jedstedt G, Nylander O. $\beta$-Endorphin and enkephalins stimulate duodenal mucosal alkaline secretion in the rat in vivo. Gastroenterology. 1986;90(2):368-72.

10. Vahedi H, Ansari R, Mir-Nasseri MM, Jafari E. Irritable bowel syndrome: a review article. Middle East J Dig Dis. 2010;2(2):66-77.

11. Holzer P. Opioid receptors in the gastrointestinal tract. Regul Pept. 2009;155(1-3):11-7.

12. Carabotti M, Scirocco A, Maselli MA, Severi C. The gut-brain axis: interactions between enteric microbiota, central and enteric nervous systems. Ann Gastroenterol. 2015;28(2):203-209.

13. Bourdeanu L, Loseth DB, Funk M. Management of opioid-induced sedation in patients with cancer. Clin J Oncol Nurs. 2005;9(6):705-11.

14. Markenson JA, Croft J, Zhang PG, Richards P. Treatment of persistent pain associated with osteoarthritis with controlled-release oxycodone tablets in a randomized controlled clinical trial. Clin J Pain. 2005;21(6):524-35. 